\title{
Increased circulating interleukin-8 in patients with resistance to thyroid hormone receptor $\alpha$
}

\author{
Anne H van der Spek ${ }^{1}$, Olga V Surovtseva', Saskia Aan', Anton T J Tool' ${ }^{2}$, \\ Annemarie van de Geer ${ }^{2}$, Korcan Demir ${ }^{3}$, Anja L M van Gucht ${ }^{4}$, \\ A S Paul van Trotsenburg ${ }^{5}$, Timo K van den Berg ${ }^{2}$, Eric Fliers ${ }^{1}$ and Anita Boelen ${ }^{1}$ \\ 'Department of Endocrinology and Metabolism, Academic Medical Center, Amsterdam, The Netherlands \\ ${ }^{2}$ Sanquin Research and Landsteiner Laboratory, Academic Medical Center, Amsterdam, The Netherlands \\ ${ }^{3}$ Division of Pediatric Endocrinology, Dokuz Eylül University, Izmir, Turkey \\ ${ }^{4}$ Department of Endocrinology, Erasmus Medical Center, Rotterdam, The Netherlands \\ ${ }^{5}$ Department of Pediatric Endocrinology, Academic Medical Center, Amsterdam, The Netherlands
}

Correspondence

should be addressed

to A Boelen

Email

a.boelen@amc.uva.nl

\begin{abstract}
Innate immune cells have recently been identified as novel thyroid hormone (TH) target cells in which intracellular TH levels appear to play an important functional role. The possible involvement of TH receptor alpha (TR $\alpha)$, which is the predominant TR in these cells, has not been studied to date. Studies in TR $\alpha^{0 / 0}$ mice suggest a role for this receptor in innate immune function. The aim of this study was to determine whether $\mathrm{TR} \alpha$ affects the human innate immune response. We assessed circulating interleukin- 8 concentrations in a cohort of 8 patients with resistance to TH due to a mutation of $\mathrm{TR} \alpha(\mathrm{RTH} \alpha)$ and compared these results to healthy controls. In addition, we measured neutrophil and macrophage function in one of these RTH $\alpha$ patients (mutation D211G). Circulating interleukin-8 levels were elevated in 7 out of $8 \mathrm{RTH} \alpha$ patients compared to controls. These patients harbor different mutations, suggesting that this is a general feature of the syndrome of RTH $\alpha$. Neutrophil spontaneous apoptosis, bacterial killing, NAPDH oxidase activity and chemotaxis were unaltered in cells derived from the RTH $\alpha$ D211G patient. RTH $\alpha$ macrophage phagocytosis and cytokine induction after LPS treatment were similar to results from control cells. The D211G mutation did not result in clinically relevant impairment of neutrophil or pro-inflammatory macrophage function. As elevated circulating IL-8 is also observed in hyperthyroidism, this observation could be due to the high-normal to high levels of circulating $T_{3}$ found in patients with RTH $\alpha$.
\end{abstract}
Key Words
thyroid hormone receptor alpha
- resistance to thyroid hormone
- interleukin-8
- macrophage
- neutrophil
- innate immunity

\section{Introduction}

Thyroid hormone (TH) is essential for normal growth and development and largely exerts its biological actions through binding to nuclear thyroid hormone receptors (1). Thyroid hormone receptors (TRs) are encoded by the thyroid hormone receptor $\alpha$ and thyroid hormone receptor $\beta$ genes (THRA and THRB, respectively), which can be alternatively spliced into several isoforms that are differentially expressed in various tissue and cell types (2). The two main isoforms of TR $\alpha$ are TR $\alpha 1$, which is a classic ligand-binding receptor and $\mathrm{TR} \alpha 2$ which is not capable of binding triiodothyronine $\left(\mathrm{T}_{3}\right)$ and whose function is not yet clear (2). TR $\alpha 1$ is the predominant isoform in cardiac and skeletal muscle, the central nervous system, bone and inflammatory cells $(3,4,5,6,7,8,9)$. There are
() 2017 The authors Published by Bioscientifica Ltd DOI: 10.1530/EC-17-0213

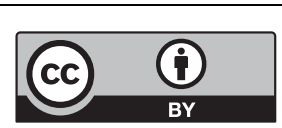

This work is licensed under a Creative Commons Attribution 4.0 International License. 
two ligand-binding TR $\beta$ isoforms: TR $\beta 1$, which is mainly present in the brain, liver and kidney, and TR $\beta 2$, which is expressed in the hypothalamus and pituitary $(1,2)$.

Patients with resistance to $\mathrm{TH}$ due to mutations in TR $\beta$ (RTH $\beta$ ) were first characterized decades ago. The first patients with inactivating mutations of the TH receptor $\alpha$ $(\mathrm{TR} \alpha)$ were only recently identified $(10,11)$. Since then, 14 different mutations in the THRA gene that result in RTH $\alpha$ have been described to date $(10,11,12,13,14,15,16,17$, $18,19)$. Despite normal to only slightly abnormal plasma $\mathrm{TH}$ levels, clinical symptoms in these patients indicate resistance to $\mathrm{TH}$ at the tissue level including growth retardation, delayed bone development, constipation and cognitive defects (20). The severity of this phenotype is variable due to the heterogeneity of the underlying THRA mutations and their varying resultant loss of receptor function (12). The incidence of RTH $\alpha$ is expected to be similar to that of RTH $\beta$, which is estimated to be around $1: 40,000$, due to the high degree of homology between the receptors (21).

Neutrophils and macrophages are both important phagocytic cells of the innate immune system. Neutrophils are the most abundant circulating leukocytes and, as the first cells to migrate to the site of infection, play an essential role in bacterial killing $(22,23)$. Macrophages are essential for the recruitment of other immune cells and can shape the immune response by eliciting either a proinflammatory or an anti-inflammatory reaction (24). Both neutrophils and macrophages are known to express TR $\alpha 1$ and other molecular elements of TH metabolism, including deiodinase enzymes $(5,6)$. Furthermore, intracellular $\mathrm{TH}$ metabolism has been linked to the immune function of these cells (25). Mice that lack TR $\alpha$ have higher levels of circulating pro-inflammatory cytokines at baseline (26), excessive secretion of pro-inflammatory cytokines by unstimulated macrophages $(26,27)$, a lower induction of the pro-inflammatory cytokine granulocyte-macrophage colony-stimulating factor (GM-CSF) during acute inflammation (5) and impaired macrophage function in an atherosclerosis model (26). These studies indicate that intracellular TH levels appear to play an important role in the function of innate immune cells. The mechanism behind these effects is currently unknown and is possibly mediated via the predominant TR in these cells: TR $\alpha$.

Although THs do appear to affect immune function at the cellular level (25), the effect of hypothyroidism on the immune response in patients is not entirely clear. A number of studies suggest that hypothyroidism impairs the innate immune response $(28,29,30)$; however, others have also described an increase in circulating pro-inflammatory cytokines in hypothyroid patients (31). Furthermore, $\mathrm{T}_{3}$ and $\mathrm{T}_{4}$ concentrations were positively correlated with several markers of inflammation in healthy euthyroid patients (32). The precise effects of altered thyroid status on the immune response in vivo remain to be determined.

The aim of this study is to determine whether TR $\alpha$ plays a role in the human innate immune response. To answer this, we assessed circulating pro-inflammatory cytokine levels in a previously described patient with RTH $\alpha$ (19) and found elevated concentrations of interleukin- 8 (IL-8). We then measured IL-8 in a larger cohort of 8 RTH $\alpha$ patients, all of whom have been previously described $(18,19)$. To further study the role of TR $\alpha$ in specific innate immune cells, we measured neutrophil and macrophage function in a single RTH $\alpha$ patient and compared these results to healthy controls. This patient was identified after his daughter was found to be a carrier of a novel TR $\alpha$ mutation as described in a recent paper by van Gucht and coworkers (19). The patient was the only RTH $\alpha$ patient in our cohort who was not being treated with L-thyroxine at the time of study, which is important as the resistance of $\mathrm{TR} \alpha$ to $\mathrm{T}_{3}$ can be overcome by high doses of $\mathrm{T}_{3}$ in the case of this mutation (19). The RTH $\alpha$ patients described here present a unique opportunity to determine whether a lack of TR $\alpha$ affects innate immune function in humans.

\section{Materials and methods}

\section{Patients and controls}

Sera from 8 previously described RTH $\alpha$ patients $(18,19)$ were obtained following written informed consent. These patients included two patients (one adult and one pediatric patient) with RTH $\alpha$ D211G as previously described by van Gucht and coworkers (19), 4 patients with RTH $\alpha$ A263S and 2 patients with RTH $\alpha 384 \mathrm{H}$ as previously described by Demir and coworkers, and van Gucht and coworkers $(18,19)$. With the exception of the adult RTH $\alpha \mathrm{D} 211 \mathrm{G}$ patient, all RTH $\alpha$ patients were undergoing treatment with L-thyroxine at the time of study. Neutrophil and macrophage function were assessed in cells derived from the adult RTH $\alpha$ D211G patient. This male patient (aged 31 years at the time of investigation) was identified as a carrier of a missense mutation D211G in TR $\alpha 1$ and TR $\alpha 2$ following the diagnosis of his daughter with the same mutation (19). The patient's phenotype at diagnosis was reported previously (19). Briefly, the patient reported mild symptoms of tissue hypothyroidism including delayed puberty and constipation. Physical examination revealed coarse facies, macrocephaly, short stature and

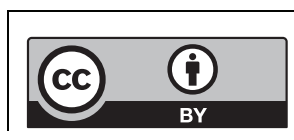

This work is licensed under a Creative Commons Attribution 4.0 International License. 
increased BMI. Blood pressure, bone mineral density and neuropsychological function tests were normal. Thyroid function tests at baseline are listed in Table 1. At the initiation of this study, the patient had never been treated with L-thyroxine. The patient reported no history of frequent bacterial infections or other signs of impaired innate immune function. Venous blood was also obtained from 11 healthy volunteers (6 males and 5 females, median age 29 years) following written informed consent. The study was approved by the Medical Ethical Committee of the Academic Medical Center Amsterdam in accordance with the principles of the Declaration of Helsinki (version Fortaleza, 2013).

\section{Cytokine measurements}

Circulating levels of IL- 8 were measured in sera from all RTH $\alpha$ patients and controls using the Human IL-8 Quantikine ELISA kit (R\&D Systems) according to manufacturer's instructions with the following modifications: sample volume was $100 \mu \mathrm{L}$, incubation time was $3 \mathrm{~h}$ and the following points were added to the standard curve: 3.6, 7.7, 15.8 and $31.3 \mathrm{pg} / \mathrm{mL}$. Samples were measured in duplicate and samples below the detection limit $(7.7 \mathrm{pg} / \mathrm{mL})$ were assigned a value of half the detection limit.

A panel of pro-inflammatory cytokines and chemokines (IL-1 $\beta$, IL-6, TNF and IL-8) were measured in supernatant of stimulated macrophages and in plasma from the adult RTH $\alpha \mathrm{D} 211 \mathrm{G}$ patient and healthy controls using the Human Inflammatory Cytokine Cytometric

Table 1 Thyroid hormone parameters of the RTH $\alpha$ patient. Values outside the reference range are indicated in bold.

\begin{tabular}{|c|c|c|}
\hline Variable & Reference values & Patient's values \\
\hline $\mathrm{T}_{4}$ & $70-150 \mathrm{nmol} / \mathrm{L}$ & 85 \\
\hline $\mathrm{fT}_{4}$ & $10-23 \mathrm{pmol} / \mathrm{L}$ & 10.1 \\
\hline $\mathrm{T}_{3}$ & $1.3-2.7 \mathrm{nmol} / \mathrm{L}$ & 2.25 \\
\hline $\mathrm{rT}_{3}$ & $0.11-0.44 \mathrm{nmol} / \mathrm{L}$ & 0.12 \\
\hline TSH & $0.5-5.0 \mathrm{mE} / \mathrm{L}$ & 1.60 \\
\hline $\mathrm{T}_{3} / \mathrm{T}_{4}(\times 100)$ & $1.42-3.05$ & 2.65 \\
\hline $\mathrm{T}_{3} / \mathrm{rT}_{3}$ & $3.1-13.0$ & 18.75 \\
\hline Thyroglobulin & 0-45 pmol/L & 13 \\
\hline IGF-1 & 8-41 nmol/L & 24 \\
\hline Hemoglobin & $8.5-10.5 \mathrm{mmol} / \mathrm{L}$ & 7.3 \\
\hline MCV & $80-100 \mathrm{fL}$ & 98.2 \\
\hline Ferritin & $25-300 \mu \mathrm{g} / \mathrm{L}$ & 272 \\
\hline
\end{tabular}

Reproduced, with permission, from van Gucht AL, Meima ME, ZwavelingSoonawala N, Visser WE, Fliers E, Wennink JM, Henny C, Visser TJ, Peeters RP \& van Trotsenburg AS. Resistance to thyroid hormone alpha inan 18-month-old girl: clinical, therapeutic, and molecular characteristics, Thyroid, 2016, vol 26, pages 338-346 (19).
Bead Array kit (BD Biosciences, Franklin Lakes, NJ, USA). Samples were run in triplicate on a FACS Calibur flow cytometer (BD Biosciences). All samples were measured in the same run. Data were analyzed using FlowJo software (version 10).

\section{Cell isolation and culture}

Neutrophils were isolated as described previously $(33,34)$. Briefly, heparinized venous blood was subjected to density gradient centrifugation over isotonic Percoll $(1.076 \mathrm{~g} / \mathrm{mL})$. Peripheral blood mononuclear cells (PBMC's) were collected and used for monocyte isolation (see below). The pellet containing erythrocytes and granulocytes was harvested. Following erythrocyte lysis, neutrophils were washed and re-suspended in HEPES-buffered medium $\left(132 \mathrm{mM} \mathrm{NaCl}, 6 \mathrm{mM} \mathrm{KCl}, 1 \mathrm{mM} \mathrm{CaCl}, 1 \mathrm{mM} \mathrm{MgSO}{ }_{4}\right.$, $1.2 \mathrm{mM} \mathrm{K} \mathrm{HPO}_{4}, 20 \mathrm{mM}$ HEPES, $1 \mathrm{mg} / \mathrm{mL}$ glucose, and $0.5 \%$ (wt/vol) human serum albumin, pH 7.4). Cells were kept at room temperature (RT) until use. Neutrophil purity was assessed using flow cytometry.

Monocytes were separated from PBMCs by positive selection using a MACS magnetic cell separation kit in combination with anti-CD14 magnetic beads (Miltenyi Biotec, Leiden, the Netherlands) according to manufacturer's instructions. Monocytes were washed and re-suspended in differentiation medium (RPMI-1640 medium (Lonza, Basel, Switzerland) with 2\% human pooled AB serum (Sigma Aldrich), $2.5 \mathrm{ng} / \mathrm{mL}$ of human M-CSF (eBioscience, San Diego, CA, USA) and 10 U/mL of penicillin and streptomycin (Lonza) plated at $1 \times 10^{6} / \mathrm{mL}$ ) (35). Cells were cultured at $37^{\circ} \mathrm{C}$ and $5 \% \mathrm{CO}_{2}$ for 7 days. On day 7 , differentiation medium was removed and cells were subsequently cultured in RPMI-1640 medium (Lonza) with $10 \%$ fetal calf serum. Macrophage differentiation was assessed visually. Macrophage purity was checked using flow cytometry.

\section{Neutrophil bacterial killing}

Neutrophil in vitro bacterial killing of Escherichia coli (strain ML-35) and Staphylococcus aureus (strain 502A) was measured as described previously $(36,37)$. Briefly, bacteria were grown aerobically at $37^{\circ} \mathrm{C}$ until logarithmic growth was reached. Bacteria were washed and re-suspended at an OD 600 of 1 (i.e. 109 bacteria/mL). After opsonization, bacteria were added to neutrophils at a ratio of 5:1 and incubated at $37^{\circ} \mathrm{C}$ for the indicated time period. At the desired time points, samples were taken and neutrophils were lysed in water ( $\mathrm{pH}$ 11.0). Serial dilutions of lysates

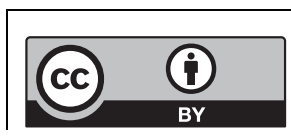

This work is licensed under a Creative Commons Attribution 4.0 International License. 
were plated and incubated at $37^{\circ} \mathrm{C}$ overnight after which colony-forming units (CFU) were counted from which the percentage of neutrophil bacterial killing was calculated. The bacterial killing assay with neutrophils from the TR $\alpha$-deficient patient were run in parallel with a day control and compared to a preexisting database of healthy controls ( $n=32$ for $E$. coli and $n=36$ for $S$. aureus).

\section{Neutrophil NADPH oxidase activity and chemotaxis}

Nicotinamide adenine dinucleotide phosphate-oxidase (NADPH oxidase) activity was measured as described previously (38). Briefly, extracellular hydrogen peroxidase $\left(\mathrm{H}_{2} \mathrm{O}_{2}\right)$ release in response to stimuli was measured using the Amplex Red (10-acetyl-3,7-dihydroxyphenoxazine) Hydrogen Peroxidase Assay kit (Molecular Probes). Phorbol 12-myristate 13-acetate (PMA, $100 \mathrm{ng} / \mathrm{mL}$ ), unopsonized zymosan $(1 \mathrm{mg} / \mathrm{mL})$, serum-treated zymosan $(\mathrm{STZ}, 1 \mathrm{mg} / \mathrm{mL})$, platelet-activating factor (PAF, $1 \mu \mathrm{M}$ ) followed by formyl-Met-Leu-Phe (fMLP, $1 \mu \mathrm{M}$ ) were used as stimuli (all Sigma Aldrich). Fluorescence was measured at 30-s intervals for $20 \mathrm{~min}$ with the Infinite 200 PRO (Tecan, Mannedorf, Switzerland). Results were compared to a day control and to the normal range of historical controls $(n=162)$.

Neutrophil migration toward various chemotactic stimuli was measured using $3 \mu \mathrm{m}$ pore-size Fluoroblock inserts (Corning), in a Falcon 24-well plate as described previously (39). Neutrophils were fluorescently labeled with calcein AM (Thermo Fisher Scientific) and the following stimuli were used: complement component $5 \mathrm{a}$ (C5a), interleukin 8 (IL-8) and PAF. Results were compared to a day control, and to the normal range of historical controls $(n=132)$.

\section{Neutrophil apoptosis}

Spontaneous apoptosis was assessed in freshly isolated unstimulated neutrophils. Cells were incubated in a shaking water bath at $37^{\circ} \mathrm{C}$ for up to $24 \mathrm{~h}$. Samples were harvested at the appropriate time points and double stained for Annexin $\mathrm{V}$ and propidium iodide (both BD Biosciences) according to manufacturer's instructions. Samples were acquired on a BD FACS Canto II flow cytometer, and data were analyzed using FlowJo software (v.10).

\section{Macrophage phagocytosis}

Differentiated macrophages were incubated in a 96-well plate $\left(5 \times 10^{4} /\right.$ well $)$ with opsonized pHrodo green zymosan
BioParticles conjugate (Molecular Probes) for $2 \mathrm{~h}$ at $37^{\circ} \mathrm{C}$. pHrodo is a fluorogenic dye that strongly increases in fluorescence as the $\mathrm{pH}$ of its surroundings decreases. Since the extracellular environment is at a neutral $\mathrm{pH}$ and the intraphagosomal environment is highly acidic, the amount of fluorescence generated is an indirect measure for the amount of phagocytosed particles. Fluorescence was quantified on a Varioskan Flash plate reader (Thermo Fisher Scientific).

\section{Macrophage stimulation, RNA isolation and qPCR}

Differentiated macrophages were incubated with or without $100 \mathrm{ng} / \mathrm{mL}$ lipopolysaccharide (LPS or bacterial endotoxin, Escherichia coli strain 055:B5; Sigma Aldrich) for $3 \mathrm{~h}$ after which medium was harvested for cytokine measurements (see below) and cells were processed for RNA isolation using the High Pure RNA isolation kit (Roche). cDNA was synthesized with equal RNA input using AMV Reverse Transcriptase enzyme with oligo d(T) primers (Roche). A cDNA synthesis reaction without reverse transcriptase was included as a control for genomic DNA contamination. Quantitative real-time PCR was carried out using the Lightcycler 480 (Roche) and SensiFAST SYBR No-ROX (Bioline, Taunton, MA, USA). Data were analyzed using LinReg software. The mean of the efficiency was calculated for each assay, and samples that deviated more than 0.05 of the efficiency mean value were excluded from the analysis (0-5\%). Primer sequences for HPRT1 (hypoxanthine phosphoribosyltransferase 1 (HPRT)), TNF (tumor necrosis factor $\alpha(\mathrm{TNF} \alpha)$ ) and CXCL8 (interleukin-8 (IL-8)) were published previously $(40,41,42,43)$. Primer sequences for IL1B (interleukin$1 \beta$ (IL-1 $\beta)$ ) and IL6 (interleukin-6 (IL-6)) were derived from the Harvard Primer Bank (numbers 221139821c1, $27894305 \mathrm{c} 1$ and $224831235 \mathrm{c} 1$, respectively). Primers were newly designed for the reference gene EEF1A1 (eukaryotic translation elongation factor 1 alpha 1 ; Ef $1 \alpha 1$ : forward primer 5'-TTTTCGCAACGGGTTTGCC-3' , reverse primer: 5'-TTGCCCGAATCTACGTGTCC-3', annealing temperature $65^{\circ} \mathrm{C}$ ). Calculated values were normalized using the geometric mean of the reference genes Ef $1 \alpha 1$ and HPRT.

\section{Statistics}

Statistical analysis was performed in GraphPad Prism, version 7.01. Differences in serum IL-8 levels between controls and RTH $\alpha$ patients were tested using an unpaired

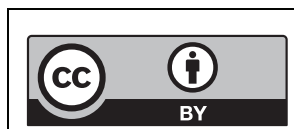

This work is licensed under a Creative Commons Attribution 4.0 International License. 


\section{IL-8 serum}

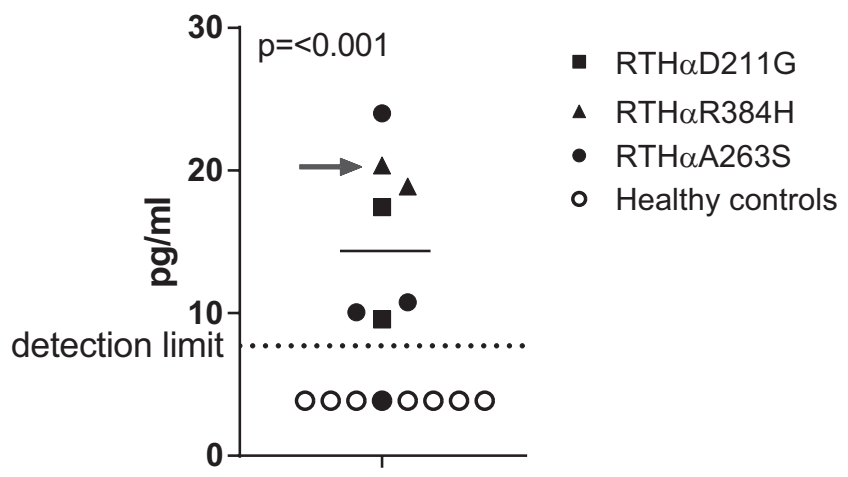

Figure 1

Serum IL-8 levels are increased in RTH $\alpha$. IL-8 concentrations were quantified using an ELISA in serum samples from RTH $\alpha$ patients (filled symbols, $n=8)$ and healthy controls $(O, n=8)$. CRP levels were measured in the same serum sample. The detection limit of the assay is indicated $(7.7 \mathrm{pg} / \mathrm{mL})$. Samples below this limit were assigned a value of half of the detection limit $(3.85 \mathrm{pg} / \mathrm{mL})$. CRP levels were within the normal range $(<5 \mathrm{mg} / \mathrm{L})$ in all samples with the exception of one RTH $\alpha$ R384H patient (indicated with gray arrow) who had a slightly elevated CRP of $7.8 \mathrm{mg} / \mathrm{L}$ without clinical signs of illness. The mean of the RTH $\alpha$ samples is

indicated. The $P$ value indicated represents an unpaired Student's $t$-test.

Student's t-test. $P<0.05$ was considered significant. Due to the study design, it was not possible to test whether differences in neutrophil and macrophage function between the single RTH $\alpha$ patient, and the healthy controls were statistically significant. Instead, we determined whether the results from the RTH $\alpha$ patient were within the range of normal controls. If values were outside this range, control data were tested for normality using the Shapiro-Wilk test. In the case of normal distribution, a $Z$-score was calculated for the RTH $\alpha$ values. $Z$-scores that were $>1.96$ or $<-1.96$ (significance levels for $\alpha=0.05$ ) are listed.

\section{Results}

\section{RTH $\alpha$ leads to an increase in circulating IL-8 concentrations}

Plasma levels of selected pro-inflammatory cytokines and chemokines were measured in samples from both healthy controls and the adult RTH $\alpha \mathrm{D} 211 \mathrm{G}$ patient. IL-1 $\beta$, IL-6, TNF, IL12p70 and IL-10 were below the detection limit of our assay $(2.5-5 \mathrm{pg} / \mathrm{mL})$ in all samples. However, we were able to detect IL- 8 in both plasma of healthy controls and plasma from the RTH $\alpha$ patient. Plasma IL-8 in the RTH $\alpha$ patient was found to be higher than that in the healthy control group.

Following this finding, we measured IL-8 in sera from a cohort of previously described RTH $\alpha$ patients with different causative mutations to determine whether increased circulating IL- 8 was a general feature of RTH $\alpha$ or specific to the D211G mutation. In total, sera from 7 additional patients were obtained. These patients included another patient with RTH $\alpha 211 \mathrm{G}$ as previously
A
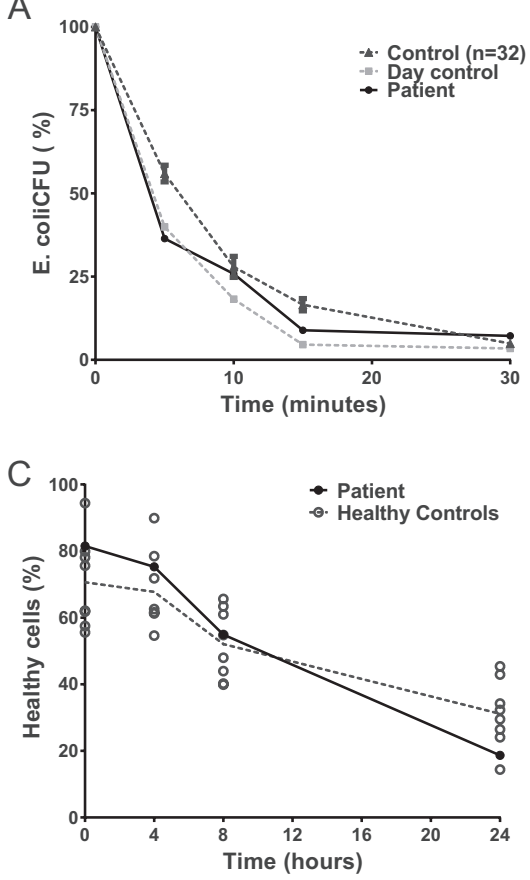

B
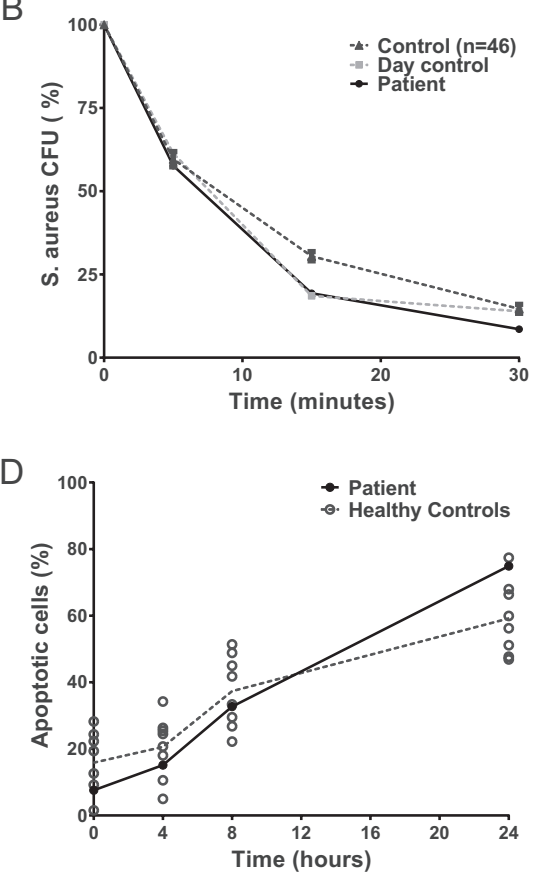

Figure 2

RTH $\alpha$ neutrophils show unchanged bacterial killing and survival ex vivo. (A) and (B) Freshly isolated neutrophils were incubated with live opsonized $E$. coli (A) or S. aureus (B) at $37^{\circ} \mathrm{C}$. Graphs indicate the remaining percentage of bacteria present at the indicated time points vs baseline levels. RTH $\alpha$ neutrophils were run in parallel with a day control. Previously acquired controls values are also shown. (C) and (D) Freshly isolated neutrophils were incubated at $37^{\circ} \mathrm{C}$. Samples were taken at the indicated time points and double stained for Annexin $\mathrm{V}$ and propidium iodide, markers for apoptosis and cell death, respectively. The percentage of healthy cells (C) and the percentage of Annexin V-positive, or apoptotic, cells (D) are indicated over time. 
A

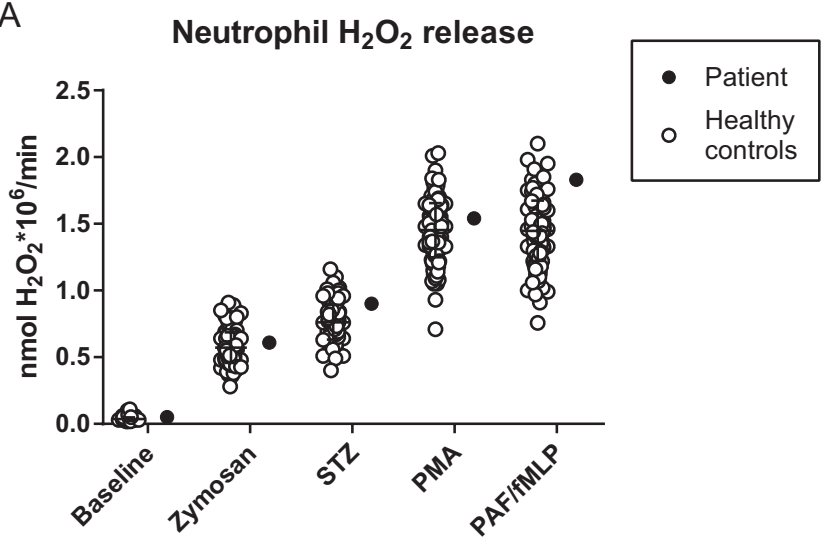

B Neutrophil chemotaxis

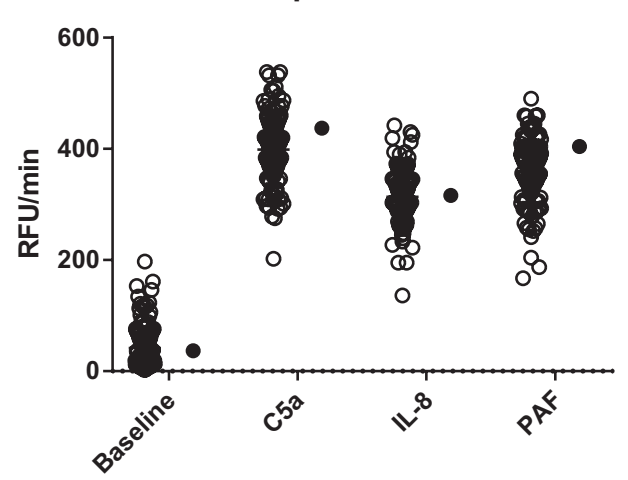

- Patient Healthy controls

Figure 3

Neutrophil $\mathrm{H}_{2} \mathrm{O}_{2}$ release and chemotaxis are unchanged in an RTHo patient. (A) Neutrophil hydrogen peroxide $\left(\mathrm{H}_{2} \mathrm{O}_{2}\right)$ release in response to stimuli. STZ, serum-treated zymosan; PMA, phorbol 12-myristate 13-acetate; PAF, platelet-activating factor; fMLP, formyl-Met-Leu-Phe. Mean \pm S.D. is indicated for data from healthy controls. (B) Migration of fluorescently labeled neutrophils toward various chemotactic stimuli. C5a, complement component 5a; IL-8, interleukin 8; PAF, platelet-activating factor. Data are indicated in relative fluorescent units (RFU) per minute. Mean \pm S.D. is indicated for data from healthy controls.

described by van Gucht and coworkers (19), 4 patients with RTH $\alpha$ A263S and 2 patients with RTH $\alpha$ R384H all as previously described by Demir and coworkers, and van Gucht and coworkers $(18,19)$. IL-8 was measured in all of the additional samples, together with samples from the original patient and controls. IL- 8 was found to be below the detection limit in all healthy controls and significantly elevated in RTH $\alpha$ patients (Fig. 1). Both healthy controls and RTH $\alpha$ patients reported no signs of illness on the day of blood draw. C-reactive protein (CRP), a highly specific determinant of inflammation, was measured in the same serum sample in which IL- 8 was measured. One RTH $\alpha$ patient had a slightly elevated CRP of $7.8 \mathrm{mg} / \mathrm{L}$ (Fig. 1, reference value: $<5 \mathrm{mg} / \mathrm{L}$ ). All the remaining controls and patients had CRP concentrations within the normal range.
Neutrophil survival, bacterial killing, $\mathrm{H}_{2} \mathrm{O}_{2}$ production and chemotaxis are unaffected in RTH $\alpha$

To determine whether RTH $\alpha$ affected not only circulating cytokine levels, but also innate immune cell function, we measured neutrophil and macrophage function in the adult RTH $\alpha$ D211G patient and healthy controls.

Various important neutrophil effector functions were analyzed in neutrophils derived from the RTH $\alpha 211 \mathrm{G}$ patient and cells derived from healthy controls. Neutrophils with an inactivating $\mathrm{TR} \alpha$ mutation were incubated with live E. coli and S. aureus and showed normal bacterial killing compared to a previously acquired dataset of controls and a day control run in parallel (Fig. 2A and B). Spontaneous neutrophil apoptosis (i.e. neutrophil lifespan) was also unchanged in RTH $\alpha$ neutrophils when compared to neutrophils derived from controls (Fig. 2C and D). The ability of RTH $\alpha$ neutrophils to migrate toward the chemotactic stimuli C5a, IL-8 and PAF was within the normal range, as was their ability to produce $\mathrm{H}_{2} \mathrm{O}_{2}$ upon stimulation with various pro-inflammatory stimuli (Fig. 3). $\mathrm{H}_{2} \mathrm{O}_{2}$ production is a measure for NADPH oxidase activity, which is an essential component of the neutrophil bacterial killing machinery (23). In conclusion, RTH $\alpha$ in this patient does not result in changes in the ability of

\section{Phagocytosis Macrophages}

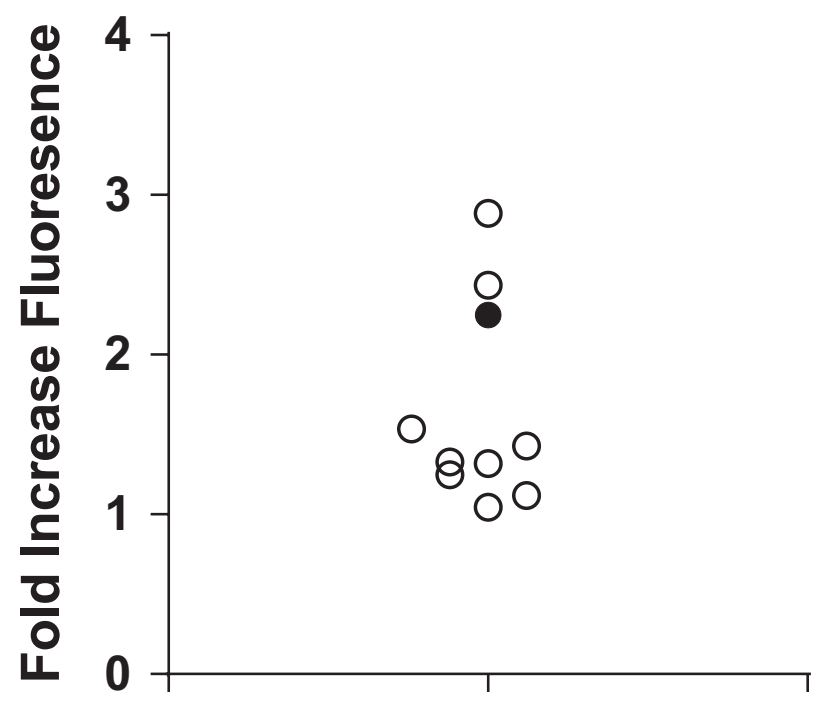

Figure 4

Macrophage phagocytosis is unchanged in an RTH $\alpha$ patient. Macrophages from the RTH $\alpha$ patient $(\bullet)$ and healthy controls $(O)$ were incubated with pHrodo-labeled zymosan (yeast particles) for $2 \mathrm{~h}$ at $37^{\circ} \mathrm{C}$. pHrodo becomes fluorescent at a low $\mathrm{pH}$ such as that present in phagosomes. The fold increase in relative fluorescent units vs pHrodo-labeled zymosan alone is shown.

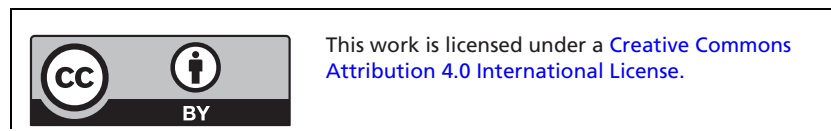


A

IL-1 $\beta$

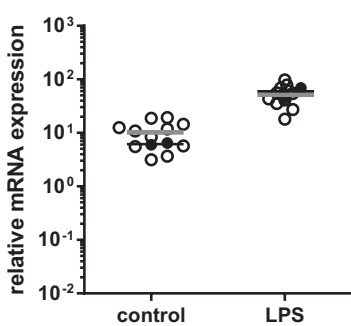

B

IL-1 $\beta$

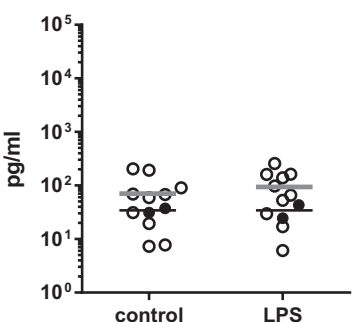

IL-6

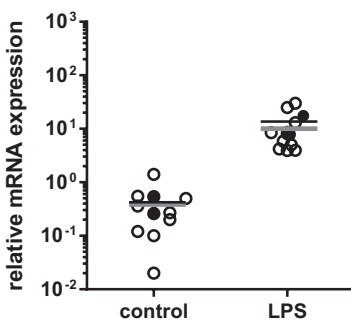

IL-6

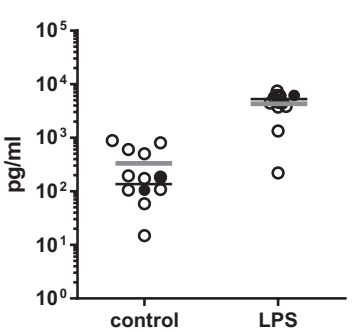

$\mathrm{TNF} \alpha$

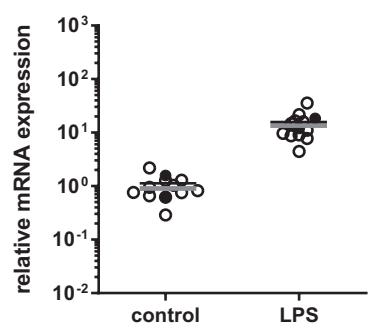

TNF

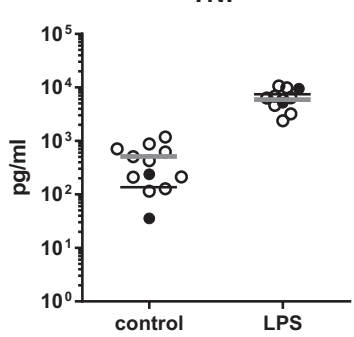

IL-8

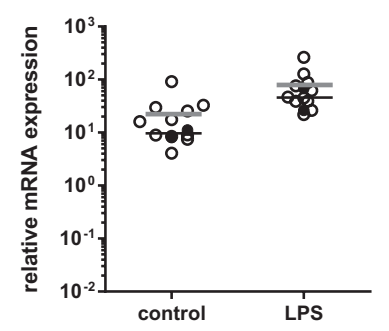

IL-8

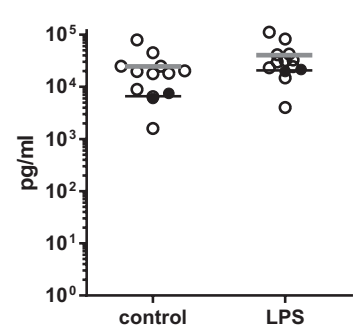

Figure $\mathbf{5}$

Macrophage pro-inflammatory cytokine levels are unchanged at baseline and after LPS stimulation in an RTH $\alpha$ patient; Macrophages from the RTH $\alpha$ patient $(\bullet)$ and healthy controls $(O)$ were incubated with or without LPS $(100 \mathrm{ng} / \mathrm{mL})$ for $3 \mathrm{~h}$. Cytokine relative mRNA expression (A) and secreted protein concentrations (B) are depicted. For the RTH $\alpha$ patient results from two independent experiments are shown.

neutrophil to migrate toward, recognize, phagocytose and kill bacteria.

\section{Pro-inflammatory macrophage function is not altered in RTH $\alpha$}

Several essential aspects of pro-inflammatory macrophage function were measured in macrophages derived from the RTH $\alpha 211 \mathrm{G}$ patient and healthy controls. Phagocytosis, determined by the cells ability to engulf fluorescent particles, was found to be unchanged in RTH $\alpha$ macrophages compared to control macrophages (Fig. 4). Macrophages were also stimulated with LPS, a bacterial cell wall component that acts as a strong pro-inflammatory stimulus. LPS stimulation resulted in a robust induction of the pro-inflammatory cytokines IL-1 $\beta$, IL-6, TNF $\alpha$ and IL-8 at the transcriptional level (Fig. 5A) and at the protein level (Fig. 5B). The response in RTH $\alpha$ macrophages was within the range of healthy control cells, both at the transcriptional and at the secretory/protein level (Fig. 5).

\section{Discussion}

Innate immune cells have recently been identified as novel TH target cells (25). It is currently unknown whether the effects of TH in innate immune cells are mediated via $\mathrm{TR} \alpha$, the predominant TR isoform in these cells. The aim of this study is to determine whether $\mathrm{TR} \alpha$ plays a role in innate immune function in humans. More insight into the effects of an inactivating TR $\alpha$ mutation can lead to improved future treatment of RTH $\alpha$ patients, and greatly increase the understanding of this syndrome and its clinical and physiological consequences. We are the first to study the effects of RTH $\alpha$ on innate immunity in humans.

We find elevated levels of circulating IL-8 in RTH $\alpha$ patients. IL-8, also known as CXCL8, is a potent proinflammatory chemokine whose primary function is to recruit and activate inflammatory cells, mainly neutrophils, to the site of infection via a chemotactic gradient (44). IL-8 is expressed in humans, but there is no rodent equivalent (44). As IL-8 expression and secretion were not elevated in RTH $\alpha$ macrophages, the increase in circulating IL-8 is most likely due to increased production by another cell type. Interestingly, elevated circulating IL-8 levels have also been described in hyperthyroidism (both Graves' disease and toxic multinodular goiter) (45). Furthermore, $\mathrm{T}_{3}$ induces IL-8 production in bone marrow stromal cells and a human osteoblast cell line (46), suggesting that the increase in circulating IL-8 could be a consequence of high circulating $\mathrm{T}_{3}$ concentrations, rather than a cause of autoimmune thyroid disease. RTH $\alpha$ patients tend to have high-normal to high levels of circulating $\mathrm{T}_{3}$ (12); this could potentially result in http://www.endocrineconnections.org DOI: 10.1530/EC-17-0213 (c) 2017 The authors Published by Bioscientifica Ltd
This work is licensed under a Creative Commons Attribution 4.0 International License. 
increased levels of IL-8. As elevated IL-8 was observed in patients both on and off levothyroxine, it appears to be an effect of the underlying condition, not its treatment.

Intracellular $\mathrm{TH}$ metabolism is thought to play an important role in the bacterial killing abilities of neutrophils via the induction of type 3 deiodinase (D3) $(6,25,47,48,49)$. The mechanism behind this remains unclear (25). One of the possibilities is that the modulation of intracellular $\mathrm{T}_{3}$ levels by D3 could result in an effect through changes in TR occupancy and subsequent $\mathrm{T}_{3}$-dependent gene transcription. TR $\alpha$ is the predominant receptor isoform in both neutrophils and macrophages $(5,6)$. In macrophages, intracellular $T_{3}$ availability and action also appear to be important for pro-inflammatory function $(5,25)$. Our results in this patient suggest that the effects of intracellular TH metabolism on neutrophil and macrophage function are not mediated via the TR $\alpha$. However, as the D211G mutation is a relatively mild mutation, in which TR $\alpha 1$ has reduced transcriptional activity which can be overcome by high concentrations of $\mathrm{T}_{3}$ (100 nM (19)), we cannot exclude the possibility that some transcriptional activity of the receptor is preserved in cells from this RTH $\alpha$ patient. Another possible explanation could be that the effects of $T_{3}$ in these cells are mediated via pathways that do not require binding to the $\mathrm{TR}$, such as the signaling pathway involving the plasma membrane integrin receptor av $\beta 3$ (50). Other authors have suggested that the effects of extracellular TH on macrophages are mediated via this receptor, resulting in the activation of the ERK1/2 and PI3K pathways (51). Whether these pathways could also be involved in intracellular $\mathrm{TH}$ signaling is currently unknown.

Interestingly, macrophages derived from $\mathrm{TR} \alpha^{0 / 0}$ mice do exhibit altered function. TR $\alpha^{0 / 0}$ mice show deficient macrophage cholesterol efflux, increased aortic inflammation, elevated serum pro-inflammatory cytokine levels and increased macrophage pro-inflammatory cytokine expression and secretion $(26,27)$. However, we do not find changes in macrophage cytokine induction in human macrophages derived from an RTH $\alpha$ patient compared to healthy controls. This discrepancy could be due to the fact that $\mathrm{TR} \alpha^{0 / 0}$ mice are completely deficient for TR $\alpha$, whereas RTH $\alpha$ patients exhibit decreased sensitivity for $\mathrm{T}_{3}$ but retain the dominant negative activity of the receptor $(52,53)$.

The main limitation of the functional neutrophil and macrophage assays in this study is the fact that material from only one untreated RTH $\alpha$ patient was studied. The functional leukocyte assays using RTH $\alpha$ leukocytes were repeated independently yielding similar results; we therefore believe that the lack of phenotypical abnormalities in RTH $\alpha$ neutrophils and macrophages is consistent, at least in the case of the D211G mutation. However, as mutations resulting in $\mathrm{RTH} \alpha$ are heterozygous, we cannot exclude that other TR $\alpha$ mutations, with for example, a more severe loss of receptor function, might affect leukocyte function. As leukocytes need to be isolated from heparinized venous blood within several hours after the blood draw, obtaining and analyzing cells from larger numbers of patients is logistically very complicated due to the very small number of currently available untreated RTH $\alpha$ patients. However, as we were able demonstrate elevated IL-8 in serum samples from a number of other RTH $\alpha$ patients harboring different mutations, we believe this considerably strengthens the study and confirms that increased IL-8 is a general feature of RTH $\alpha$ and not one limited to the D211G mutation.

Intracellular $\mathrm{TH}$ metabolism has been shown to be essential for adequate pro-inflammatory neutrophil and macrophage function, identifying innate immune cells as novel TH target cells (25). This study is the first to assess the role of TR $\alpha$ in human innate immune function. Our results show that $\mathrm{RTH} \alpha$ results in an increase in circulating IL-8 levels, which has also been described in hyperthyroid patients and therefore might lead to a slight increase in circulating $\mathrm{T}_{3}$. Furthermore, we demonstrate that a relatively mild mutation in the $\mathrm{TR} \alpha$ does not result in clinically relevant impairment of neutrophil or proinflammatory macrophage function.

\section{Declaration of interest}

The authors declare that there is no conflict of interest that could be perceived as prejudicing the impartiality of the research reported.

\section{Funding}

This work was supported by the AMC Graduate School PhD Scholarship (A H v d S).

\section{Author contribution statement}

$A H \vee d S, E F$ and $A B$ designed the experiments. A H $v d S, O \vee S, S A, A T$ $J T, A \vee d G$ and $A L M \vee G$ performed the experiments. $K D$ and $A S P \vee T$ provided patient material. T K $\vee d B, E F$ and $A B$ supervised experiments. A $\mathrm{H} \vee \mathrm{d} S, \mathrm{EF}$ and $\mathrm{A} B$ wrote the original draft of the manuscript. All authors read and approved the final version of the manuscript.

\section{Acknowledgments}

The authors would like to thank Alex de Vos (Center for Experimental and Molecular Medicine, AMC, Amsterdam) for providing expertise and technical support with cytokine measurements in human serum and cell supernatants.

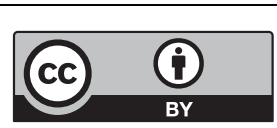

This work is licensed under a Creative Commons Attribution 4.0 International License. 


\section{References}

1 Brent GA. Mechanisms of thyroid hormone action. Journal of Clinical Investigation 2012122 3035-3043. (doi:10.1172/JCI60047)

2 Cheng SY, Leonard JL \& Davis PJ. Molecular aspects of thyroid hormone actions. Endocrine Reviews 201031 139-170. (doi:10.1210/ er.2009-0007)

3 Wallis K, Dudazy S, van Hogerlinden M, Nordstrom K, Mittag J\& Vennstrom $\mathrm{B}$. The thyroid hormone receptor alpha1 protein is expressed in embryonic postmitotic neurons and persists in most adult neurons. Molecular Endocrinology 201024 1904-1916. (doi:10.1210/me.2010-0175)

4 Bassett JH \& Williams GR. The skeletal phenotypes of TRalpha and TRbeta mutant mice. Journal of Molecular Endocrinology 200942 269-282. (doi:10.1677/JME-08-0142)

5 Kwakkel J, Surovtseva OV, de Vries EM, Stap J, Fliers E \& Boelen A. A novel role for the thyroid hormone-activating enzyme type 2 deiodinase in the inflammatory response of macrophages. Endocrinology 2014155 2725-2734. (doi:10.1210/en.2013-2066)

6 van der Spek AH, Bloise FF, Tichgelaar W, Dentice M, Salvatore D, van der Wel NN, Fliers E \& Boelen A. The thyroid hormone inactivating enzyme type 3 deiodinase is present in bactericidal granules and the cytoplasm of human neutrophils. Endocrinology 2016157 3293-3305. (doi:10.1210/en.2016-1103)

7 Milanesi A, Lee JW, Kim NH, Liu YY, Yang A, Sedrakyan S, Kahng A, Cervantes V, Tripuraneni N, Cheng SY, et al. Thyroid hormone receptor alpha plays an essential role in male skeletal muscle myoblast proliferation, differentiation, and response to injury. Endocrinology 2016157 4-15. (doi:10.1210/en.2015-1443)

8 Bassett JH, Boyde A, Zikmund T, Evans H, Croucher PI, Zhu X, Park JW, Cheng SY \& Williams GR. Thyroid hormone receptor alpha mutation causes a severe and thyroxine-resistant skeletal dysplasia in female mice. Endocrinology 2014155 3699-3712. (doi:10.1210/ en.2013-2156)

9 Macchia PE, Takeuchi Y, Kawai T, Cua K, Gauthier K, Chassande O, Seo H, Hayashi Y, Samarut J, Murata Y, et al. Increased sensitivity to thyroid hormone in mice with complete deficiency of thyroid hormone receptor alpha. PNAS 200198 349-354. (doi:10.1073/ pnas.011306998)

10 Bochukova E, Schoenmakers N, Agostini M, Schoenmakers E, Rajanayagam O, Keogh JM, Henning E, Reinemund J, Gevers E, Sarri M, et al. A mutation in the thyroid hormone receptor alpha gene. New England Journal of Medicine 2012366 243-249. (doi:10.1056/NEJMoa1110296)

11 van Mullem A, van Heerebeek R, Chrysis D, Visser E, Medici M, Andrikoula M, Tsatsoulis A, Peeters R \& Visser TJ. Clinical phenotype and mutant TRalpha1. New England Journal of Medicine 2012366 1451-1453. (doi:10.1056/NEJMc1113940)

12 Moran C \& Chatterjee K. Resistance to thyroid hormone alphaemerging definition of a disorder of thyroid hormone action. Journal of Clinical Endocrinology and Metabolism $20161012636-2639$. (doi:10.1210/jc.2016-2317)

13 Moran C, Agostini M, Visser WE, Schoenmakers E, Schoenmakers N, Offiah AC, Poole K, Rajanayagam O, Lyons G, Halsall D, et al. Resistance to thyroid hormone caused by a mutation in thyroid hormone receptor (TR)alpha1 and TRalpha2: clinical, biochemical, and genetic analyses of three related patients. Lancet Diabetes and Endocrinology 20142 619-626. (doi:10.1016/S2213-8587(14)70111-1)

14 Moran C, Schoenmakers N, Agostini M, Schoenmakers E, Offiah A, Kydd A, Kahaly G, Mohr-Kahaly S, Rajanayagam O, Lyons G, et al. An adult female with resistance to thyroid hormone mediated by defective thyroid hormone receptor alpha. Journal of Clinical Endocrinology and Metabolism 201398 4254-4561. (doi:10.1210/ jc.2013-2215)

15 van Mullem AA, Chrysis D, Eythimiadou A, Chroni E, Tsatsoulis A, de Rijke YB, Visser WE, Visser TJ \& Peeters RP. Clinical phenotype of a new type of thyroid hormone resistance caused by a mutation of the TRalpha1 receptor: consequences of LT4 treatment. Journal of Clinical Endocrinology and Metabolism 201398 3029-3038. (doi:10.1210/jc.2013-1050)

16 Tylki-Szymanska A, Acuna-Hidalgo R, Krajewska-Walasek M, LeckaAmbroziak A, Steehouwer M, Gilissen C, Brunner HG, Jurecka A, Różdżyńska-Świątkowska A, Hoischen A, et al. Thyroid hormone resistance syndrome due to mutations in the thyroid hormone receptor alpha gene (THRA). Journal of Medical Genetics 201552 312-316. (doi:10.1136/jmedgenet-2014-102936)

17 Espiard S, Savagner F, Flamant F, Vlaeminck-Guillem V, Guyot R, Munier M, d'Herbomez M, Bourguet W, Pinto G, Rose C, et al. A novel mutation in THRA gene associated with an atypical phenotype of resistance to thyroid hormone. Journal of Clinical Endocrinology and Metabolism 2015100 2841-2848. (doi:10.1210/jc.2015-1120)

18 Demir K, van Gucht AL, Buyukinan M, Catli G, Ayhan Y, Nijat Bas V, Dündar B, Özkan B, Meima ME, Visser WE, et al. Diverse genotypes and phenotypes of three novel thyroid hormone receptor alpha mutations. Journal of Clinical Endocrinology and Metabolism 2016101 2945-2954. (doi:10.1210/jc.2016-140)

19 van Gucht AL, Meima ME, Zwaveling-Soonawala N, Visser WE, Fliers E, Wennink JM, Henny C, Visser TJ, Peeters RP \& van Trotsenburg AS. Resistance to thyroid hormone alpha in an 18-month-old girl: clinical, therapeutic, and molecular characteristics. Thyroid 201626 338-346. (doi:10.1089/ thy.2015.0463)

20 Moran C \& Chatterjee K. Resistance to thyroid hormone due to defective thyroid receptor alpha. Best Practice and Research Clinical Endocrinology and Metabolism 201529 647-657. (doi:10.1016/j. beem.2015.07.007)

21 Lafranchi SH, Snyder DB, Sesser DE, Skeels MR, Singh N, Brent GA $\&$ Nelson JC. Follow-up of newborns with elevated screening T4 concentrations. Journal of Pediatrics 2003143 296-301. (doi:10.1067/ S0022-3476(03)00184-7)

22 Borregaard N. Neutrophils from marrow to microbes. Immunity 2010 33 657-670. (doi:10.1016/j.immuni.2010.11.011)

23 Kolaczkowska E \& Kubes P. Neutrophil recruitment and function in health and inflammation. Nature Reviews Immunology 201313 159-175. (doi:10.1038/nri3399)

24 Murray PJ \& Wynn TA. Protective and pathogenic functions of macrophage subsets. Nature Reviews Immunology 201111 723-737. (doi:10.1038/nri3073)

25 van der Spek AH, Fliers E \& Boelen A. Thyroid hormone metabolism in innate immune cells. Journal of Endocrinology 2017232 R67-R81. (doi:10.1530/JOE-16-0462)

26 Billon C, Canaple L, Fleury S, Deloire A, Beylot M, Dombrowicz D, Del Carmine P, Samarut J \& Gauthier K. TRalpha protects against atherosclerosis in male mice: identification of a novel antiinflammatory property for TRalpha in mice. Endocrinology 2014155 2735-2745. (doi:10.1210/en.2014-1098)

27 Furuya F, Ishii T, Tamura S, Takahashi K, Kobayashi H, Ichijo M, Takizawa S, Kaneshige M, Suzuki-Inoue K \& Kitamura K. The ligandbound thyroid hormone receptor in macrophages ameliorates kidney injury via inhibition of nuclear factor-kappaB activities. Scientific Reports 20177 43960. (doi:10.1038/srep43960)

28 Schoenfeld PS, Myers JW, Myers L \& LaRocque JC. Suppression of cell-mediated immunity in hypothyroidism. Southern Medical Journal 199588 347-349. (doi:10.1097/00007611-199503000-00019)

29 Pillay K. Congenital hypothyroidism and immunodeficiency: evidence for an endocrine-immune interaction. Journal of Pediatric Endocrinology and Metabolism 199811 757-761.

30 De Vito P, Balducci V, Leone S, Percario Z, Mangino G, Davis PJ, Davis FB, Affabris E, Luly P, Pedersen JZ, et al. Nongenomic effects of thyroid hormones on the immune system cells: new targets, old players. Steroids 201277 988-995. (doi:10.1016/j. steroids.2012.02.018)

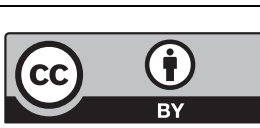

This work is licensed under a Creative Commons Attribution 4.0 International License. 
31 De Vito P, Incerpi S, Pedersen JZ, Luly P, Davis FB \& Davis PJ. Thyroid hormones as modulators of immune activities at the cellular level. Thyroid 201121 879-890. (doi:10.1089/thy.2010.0429)

32 Hodkinson CF, Simpson EE, Beattie JH, O'Connor JM, Campbell DJ, Strain JJ \& Wallace JM. Preliminary evidence of immune function modulation by thyroid hormones in healthy men and women aged 55-70 years. Journal of Endocrinology 2009202 55-63. (doi:10.1677/ JOE-08-0488)

33 Kuijpers TW, Tool AT, van der Schoot CE, Ginsel LA, Onderwater JJ, Roos D \& Verhoeven AJ. Membrane surface antigen expression on neutrophils: a reappraisal of the use of surface markers for neutrophil activation. Blood 199178 1105-1111.

34 Roos D \& de Boer M. Purification and cryopreservation of phagocytes from human blood. Methods in Enzymology 1986132 225-243.

35 Menck K, Behme D, Pantke M, Reiling N, Binder C, Pukrop T $\&$ Klemm F. Isolation of human monocytes by double gradient centrifugation and their differentiation to macrophages in tefloncoated cell culture bags. Journal of Visualized Experiments 201491 e51554. (doi:10.3791/51554)

36 Decleva E, Menegazzi R, Busetto S, Patriarca P \& Dri P. Common methodology is inadequate for studies on the microbicidal activity of neutrophils. Journal of Leukocyte Biology 200679 87-94. (doi:10.1189/ jlb.0605338)

37 van Bruggen R, Drewniak A, Tool AT, Jansen M, van Houdt M, Geissler J, van den Berg TK, Chapel H \& Kuijpers TW. Toll-like receptor responses in IRAK-4-deficient neutrophils. Journal of Innate Immunity 20102 280-287. (doi:10.1159/000268288)

38 Szilagyi K, Gazendam RP, van Hamme JL, Tool AT, van Houdt M, Vos WA, Verkuijlen P, Janssen H, Belot A, Juillard L, et al. Impaired microbial killing by neutrophils from patients with protein kinase $C$ delta deficiency. Journal of Allergy and Clinical Immunology 2015136 1404.e1-1407.e10. (doi:10.1016/j.jaci.2015.06.016)

39 Kuijpers TW, van Bruggen R, Kamerbeek N, Tool AT, Hicsonmez G, Gurgey A, Karow A, Verhoeven AJ, Seeger K, Sanal O, et al. Natural history and early diagnosis of LAD-1/variant syndrome. Blood 2007 109 3529-3537. (doi:10.1182/blood-2006-05-021402)

40 Bouaboula M, Legoux P, Pessegue B, Delpech B, Dumont X, Piechaczyk M, Casellas P \& Shire D. Standardization of mRNA titration using a polymerase chain reaction method involving co-amplification with a multispecific internal control. Journal of Biological Chemistry 1992267 21830-21838.

41 Sharif O, Bolshakov VN, Raines S, Newham P \& Perkins ND. Transcriptional profiling of the LPS induced NF-kappaB response in macrophages. BMC Immunology 200781. (doi:10.1186/1471-2172-8-1)

42 Chan SY, Franklyn JA, Pemberton HN, Bulmer JN, Visser TJ, McCabe CJ \& Kilby MD. Monocarboxylate transporter 8 expression in the human placenta: the effects of severe intrauterine growth restriction. Journal of Endocrinology 2006189 465-471. (doi:10.1677/ joe.1.06582)

43 Liu J, Cao S, Herman LM \& Ma X. Differential regulation of interleukin (IL)-12 p35 and p40 gene expression and interferon (IFN)-gamma-primed IL-12 production by IFN regulatory factor 1 . Journal of Experimental Medicine 2003198 1265-1276. (doi:10.1084/ jem.20030026)

44 Remick DG. Interleukin-8. Critical Care Medicine 200533 (Supplement 12) S466-S467.

45 Rotondi M, Coperchini F \& Chiovato L. CXCL8 in thyroid disease: from basic notions to potential applications in clinical practice. Cytokine and Growth Factor Reviews 201324 539-546. (doi:10.1016/j. cytogfr.2013.08.001)

46 Siddiqi A, Burrin JM, Wood DF \& Monson JP. Tri-iodothyronine regulates the production of interleukin- 6 and interleukin- 8 in human bone marrow stromal and osteoblast-like cells. Journal of Endocrinology 1998157 453-461. (doi:10.1677/joe.0.1570453)

47 Boelen A, Boorsma J, Kwakkel J, Wieland CW, Renckens R, Visser TJ, Fliers E \& Wiersinga WM. Type 3 deiodinase is highly expressed in infiltrating neutrophilic granulocytes in response to acute bacterial infection. Thyroid 200818 1095-1103. (doi:10.1089/thy.2008.0090)

48 Boelen A, Kwakkel J, Alkemade A, Renckens R, Kaptein E, Kuiper G, Wiersinga WM \& Visser TJ. Induction of type 3 deiodinase activity in inflammatory cells of mice with chronic local inflammation. Endocrinology 2005146 5128-5134. (doi:10.1210/en.2005-0608)

49 Boelen A, Kwakkel J, Wieland CW, St Germain DL, Fliers E \& Hernandez A. Impaired bacterial clearance in type 3 deiodinasedeficient mice infected with Streptococcus pneumoniae. Endocrinology 2009150 1984-1990. (doi:10.1210/en.2008-1133)

50 Flamant F, Cheng SY, Hollenberg AN, Moeller LC, Samarut J, Wondisford FE, Yen PM \& Refetoff S. Thyroid hormone signaling pathways: time for a more precise nomenclature. Endocrinology 2017 158 2052-2057. (doi:10.1210/en.2017-00250)

51 Chen Y, Sjolinder M, Wang X, Altenbacher G, Hagner M, Berglund P, Gao Y, Lu T, Jonsson AB \& Sjölinder H. Thyroid hormone enhances nitric oxide-mediated bacterial clearance and promotes survival after meningococcal infection. PLOS ONE 20127 e41445. (doi:10.1371/ journal.pone.0041445)

52 Gauthier K, Plateroti M, Harvey CB, Williams GR, Weiss RE, Refetoff S, Willott JF, Sundin V, Roux JP \& Malaval L. Genetic analysis reveals different functions for the products of the thyroid hormone receptor alpha locus. Molecular and Cellular Biology 200121 4748-4760. (doi:10.1128/MCB.21.14.4748-4760.2001)

53 Ortiga-Carvalho TM, Sidhaye AR \& Wondisford FE. Thyroid hormone receptors and resistance to thyroid hormone disorders. Nature Reviews Endocrinology 201410 582-591. (doi:10.1038/nrendo.2014.143)

Received in final form 21 September 2017

Accepted 28 September 2017

Accepted Preprint published online 28 September 2017 http://www.endocrineconnections.org DOI: 10.1530/EC-17-0213
C) 2017 The authors Published by Bioscientifica Ltd

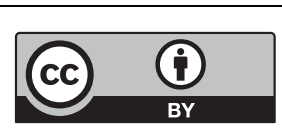

This work is licensed under a Creative Commons Attribution 4.0 International License. 